\title{
Sintaxe e semântica de non na Bíblia Hebraica: estudo para a tradução do Salmo 23
}

\author{
Syntax and semantics of חס in the Hebrew Bible: \\ Study for the translation of Psalm 23
}

\section{Osvaldo Luiz Ribeiro*}

Faculdade Unida de Vitória, Vitória, ES, Brasil

\section{Resumo}

Este artigo investiga a fenomenologia semântica e sintática da raiz hebraica no na Biblia Hebraica Stuttgartensia. Trata-se de um estudo introdutório para a tradução e a interpretação do Salmo 23. O objetivo é verificar a possibilidade de a raiz ser traduzida com o sentido de "faltar", testando-se assim a hipótese de traduzir-se Salmo 23,1 como “o Senhor é meu pastor, não faltarei”, isto é, "não morrerei”. Identificam-se nove ocorrências da raiz חסר com o sentido de "faltar": Gn 8,3.5; 18,28; 1 Re 17,14.16; Ec 9,8; Ct 7,3; Is 32,6; 51,11. Confirma-se a hipótese investigada: na BHS, חסר pode ser traduzida como "faltar", e, em termos gramaticais, a tradução é possível também para SI 23,1.

Palavras-chave: Salmo 23,1. Bíblia Hebraica. Semântica. Sintaxe. Exegese.

* OLR: PhD, e-mail: osvaldo@faculdadeunida.com.br 


\section{Abstract}

The article investigates the semantic and syntactic phenomenology of Hebrew root חסר used in the Biblia Hebraica Stuttgartensia. It is an introductory study for the translation and the interpretation of Psalm 23. The goal is to verify the possibility of the root be translated to mean "to lack", verifying the possibility of translation of Psalm 23.1 as "the Lord is my shepherd, I will not lack", that is, "I will not die". Are identified nine occurrences of חסר with the sense of "to lack": Genesis 8,3.5; 18.28; 1 Kings 17,14.16; Ecclesiastes 9.8; Song of Solomon 7.3; Isaiah 32.6; 51.11. It is confirmed the hypothesis investigated: in the BHS, חס can be translated as "to lack", and in grammatical terms, the translation is also possible to Ps 23.1.

Keywords: Psalm 23,1. Hebrew Bible. Semantics. Syntax. Exegesis.

\section{Introdução}

O objetivo do presente artigo é produzir prova retórica (GINZBURG, 2002) para decidir-se sobre a mais adequada tradução de 23,1. A raiz deve ser traduzida no sentido de "(não) ter falta" ("Yahweh é meu pastor, não terei falta") ${ }^{1}$ ou no sentido de "(não) faltar" ("Yahweh é meu pastor, não faltarei”)? O desafio da tradução do Salmo 23 impõe que, antes de se embrenhar na disputadíssima literatura especializada, domine-se a fenomenologia semântica e sintática da raiz na própria Bíblia Hebraica, a fim de se determinar, num ou noutro caso, se a proposta de tradução como "não faltarei" corresponde a um sentido usual da raiz, a um sentido identificado, mas incomum, ou se, ao contrário, a intuição investigada se chocará contra o testemunho semântico-fenomenológico e sintático-fenomenológico do conjunto dos livros da Bíblia Hebraica

1 Tão comum que se é escusado de referências singulares, as versões operam sob o regime de tradução dinâmica, e não formal. Desse modo, o que literalmente é tomado como "eu não terei falta", é transformado - nesse caso, legitimamente - em "eu não terei falta de nada" e, desde aí, na tradução consagrada, "nada me faltará". Daí a memória do Salmo 23 reverberar: "o Senhor é meu pastor, nada me faltará". 
Stuttgartensia. É por essa razão que, acompanhando-se de perto o tratamento da raiz em dicionários da língua hebraica ${ }^{2}$, se começa o conjunto de estudos necessários a um exercício de tradução e interpretação do Salmo 23 pela investigação do sentido de

Quadro 1 - Quadro sintético das ocorrências de חסר na Bíblia Hebraica

(continua)

\begin{tabular}{|c|c|c|c|}
\hline Gn 8,3 & 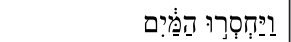 & verbo, qal & "e foram faltando as águas" \\
\hline Gn 8,5 & 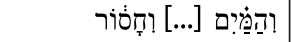 & verbo, qal & "e as águas [...] foram faltando" \\
\hline Gn 18,28 & 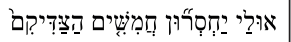 & verbo, qal & "e se faltarem cinquenta justos?" \\
\hline Ex 16,18 & 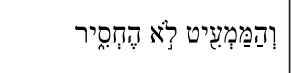 & verbo, hifil & $\begin{array}{l}\text { "e o que colhia pouco não teve } \\
\text { falta" }\end{array}$ \\
\hline Dt 2,7 & 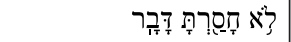 & verbo, qal & "não te faltou nada" \\
\hline Dt 8,9 & 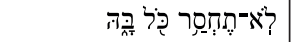 & verbo, qal & “não te faltarás nada nela” \\
\hline Dt 15,8 & 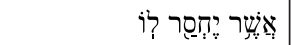 & verbo, qal & "o que falta para ele" \\
\hline Dt 28,48 & 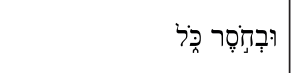 & $\begin{array}{l}\text { substantivo } \\
\text { construto }\end{array}$ & "e com falta de tudo" \\
\hline Dt 28,58 & 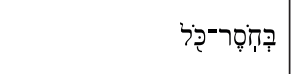 & $\begin{array}{l}\text { substantivo } \\
\text { construto }\end{array}$ & "pela falta de tudo" \\
\hline $1 \mathrm{Sm} 21,16$ & 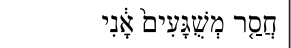 & adjetivo & "falto de doidos eu estou" \\
\hline $2 \mathrm{Sm} 3,29$ & 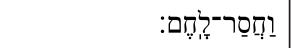 & adjetivo construto & "e falto de pão" \\
\hline $1 \operatorname{Re} 11,22$ & 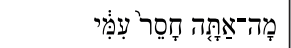 & adjetivo construto & "do que tu estás falto comigo?" \\
\hline $1 \operatorname{Re} 17,14$ & 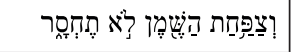 & verbo, qal & "e o jarro do óleo não faltará" \\
\hline $1 \operatorname{Re} 17,16$ & 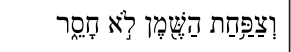 & verbo, qal & "e o jarro do óleo não faltou" \\
\hline Ne 9,21 & לְא חָסֵרוּ & verbo, qal & $\begin{array}{l}\text { "não faltaram" ou “não tiveram } \\
\text { falta”? }\end{array}$ \\
\hline Jó 30,3 & 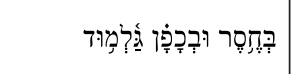 & $\begin{array}{l}\text { substantivo } \\
\text { absoluto }\end{array}$ & "de falta e de grave fome" \\
\hline SI 8,6 & 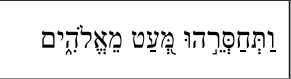 & verbo, piel & $\begin{array}{l}\text { "e tu privaste-lhe pouco } \\
\text { menos do que aos deuses" }\end{array}$ \\
\hline SI 23,1 & לְא אֶּוְסָר & verbo, qal & $\begin{array}{l}\text { "não faltarei” ou “não terei } \\
\text { falta"? }\end{array}$ \\
\hline
\end{tabular}

2 No seu conjunto, os verbetes dos dicionários constantes das referências são mutuamente intercambiáveis. Os casos citados têm apenas função representativa. 
Quadro 1 - Quadro sintético das ocorrências de חסר na Bíblia Hebraica

(conclusão)

\begin{tabular}{|c|c|c|c|}
\hline SI 34,11 & 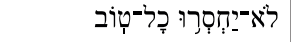 & verbo, qal & "não têm falta de coisa boa" \\
\hline $\operatorname{Pr} 6,32$ & 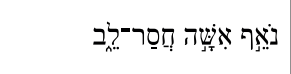 & adjetivo construto & $\begin{array}{l}\text { "adulterador de mulher, } \\
\text { falto de coração" }\end{array}$ \\
\hline $\operatorname{Pr} 7,7$ & 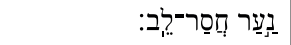 & adjetivo construto & "um jovem falto de coração" \\
\hline $\begin{array}{c}\operatorname{Pr} 9,4.16 ; 10,13 ; \\
11,12 ; 12,11\end{array}$ & חָסַר־־ֵב" & adjetivo construto & "falto de coração" \\
\hline $\operatorname{Pr} 10,21$ & 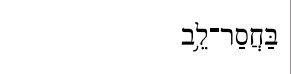 & $\begin{array}{l}\text { substantivo } \\
\text { construto }\end{array}$ & "na falta de coração" \\
\hline $\operatorname{Pr} 12,9$ & 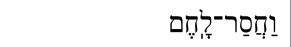 & adjetivo construto & "e é falto de pão" \\
\hline $\operatorname{Pr} 13,25$ & 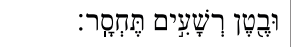 & verbo, qal & "mas o ventre dos maus terá falta" \\
\hline $\operatorname{Pr} 15,21$ & 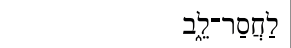 & adjetivo construto & “para um falto de pão" \\
\hline $\operatorname{Pr} 17,18 ; 24,30$ & אָדָנם חְסַר־-לֵב & adjetivo construto & "um homem falto de coração" \\
\hline $\operatorname{Pr} 28,16$ & 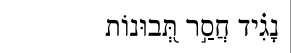 & adjetivo construto & "um líder falto de inteligência” \\
\hline $\operatorname{Pr} 28,22$ & 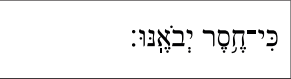 & $\begin{array}{l}\text { substantivo } \\
\text { absoluto }\end{array}$ & "que a falta virá para ele" \\
\hline $\operatorname{Pr} 31,11$ & 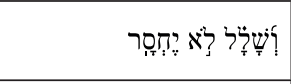 & verbo, qal & $\begin{array}{l}\text { "e de lucro ele não terá falta" } \\
\text { ou “e o lucro não faltará? }\end{array}$ \\
\hline Ec 4,8 & 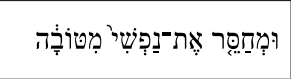 & verbo, piel & $\begin{array}{l}\text { "e privo a minha garganta } \\
\text { do que é bom" }\end{array}$ \\
\hline Ec 6,2 & 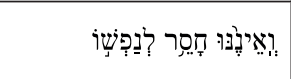 & $\begin{array}{l}\text { adjetivo } \\
\text { absoluto }\end{array}$ & $\begin{array}{l}\text { "e nada falta para a garganta } \\
\text { dele" }\end{array}$ \\
\hline Ec 9,8 & 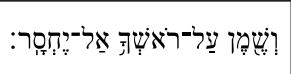 & verbo, qal & $\begin{array}{l}\text { "e óleo sobre a cabeça } \\
\text { dele não faltará" }\end{array}$ \\
\hline Ec 10,3 & 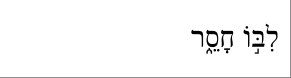 & $\begin{array}{l}\text { adjetivo } \\
\text { absoluto }\end{array}$ & “o coração dele é falto” \\
\hline Ct 7,3 & 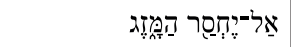 & verbo, qal & “não falta o 'vinho”" \\
\hline Is 32,6 & 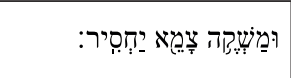 & verbo, hifil & $\begin{array}{l}\text { "e a bebida do sedento faça } \\
\text { faltar" }\end{array}$ \\
\hline Is 51,14 & 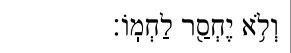 & verbo, qal & “e não faltará o pão dele" \\
\hline Jr 44,18 & חָסֵסרונוּ כָל & verbo, qal & "tivemos falta de tudo" \\
\hline Ez 4,17 & 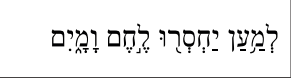 & verbo, qal & $\begin{array}{l}\text { "para que tenham falta } \\
\text { de pão e água" }\end{array}$ \\
\hline Am 4,6 & 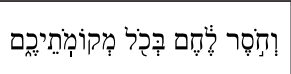 & $\begin{array}{l}\text { substantivo } \\
\text { construto }\end{array}$ & $\begin{array}{l}\text { "e falta de pão em todos } \\
\text { os vossos lugares" }\end{array}$ \\
\hline
\end{tabular}

Fonte: elaborado pelo autor. 
Conforme se depreende do quadro sintético acima, com base na Biblia Hebraica Stuttgartensia (BHS), a raiz חסר ocorre 45 vezes. Apresentadas na ordem das ocorrências na BHS, no quadro encontram-se indicadas as passagens em que ela é empregada, o contexto frasal no qual a respectiva atualização da raiz qual חסר se atualiza e uma tradução proposta. Na forma de verbo, חסר é utilizada 22 vezes, das quais 18 na forma de qal, 2 na forma de piel e 2 na forma de hifil. Na forma de substantivo, חסר ocorre 6 vezes, e na forma de adjetivo, 17 vezes.

\section{As atualizações de רor na forma de substantivo na Bíblia Hebraica}

A raiz חסר apresenta-se na forma de substantivo em Dt 28,48.58; Jó 30,3; Pr 10,21; Pr 28,22 e Am 4,6. Alonso-Schökel apresenta dois ver-

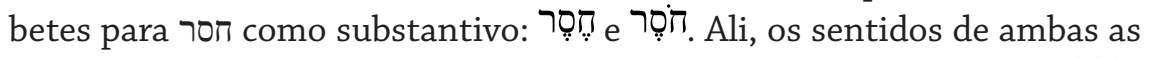
formas de substantivo não parecem diferir em grande medida. Para חֶֶ, Alonso-Schökel apresenta os seguintes sentidos: "carestia, falta, penúria,

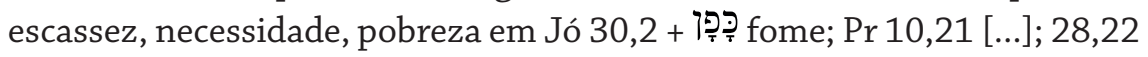
; fortuna" (ALONSO-SCHÖKEL, 1997, p. 237; cf. KLEIN, 1987, p. 226). Para רֶֶ๊, Alonso-Schökel apresenta os sentidos de "falta, escassez, neces-

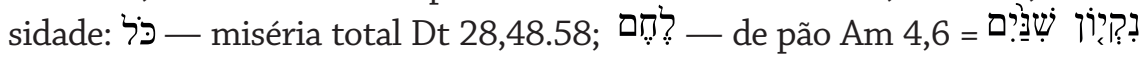
limpeza de dentes" (ALONSO-SCHÖKEL, 1997, p. 237; cf. BROWN, DRIVER e BRIGGS, 2010, p. 341).

Com efeito, em contexto narrativo de praga divina, em Dt 28,48.58 (WOODS, 2011, p. 272-283) anuncia-se grande tragédia, sofrimento e

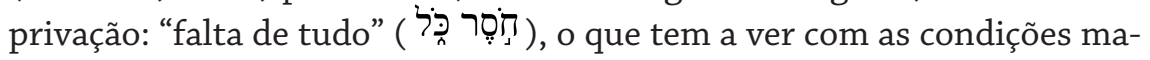
teriais de sobrevivência, já que a praga chega ao ponto de anunciar que, por falta de tudo, se comerão os próprios filhos. Entregues a esse tipo de situação, encontra-se também a gente paupérrima e expulsa da terra, que por isso vive em cavernas e no meio do mato, sem ter o que comer, e a padecer toda sorte de necessidade, vivendo com "falta e fome" (Jó 30,3:

Bem se vê que o que, na forma de substantivo, רon representa é o oposto da riqueza. De fato, segundo $\operatorname{Pr}, 28,22$, há quem corra atrás da riqueza (דiֹ), mas acabe encontrando a "falta", isto é, a pobreza (דֶֶ), o 
que, nesse caso, o deixa como aquele que padece de "falta de pão" (Am 4,6

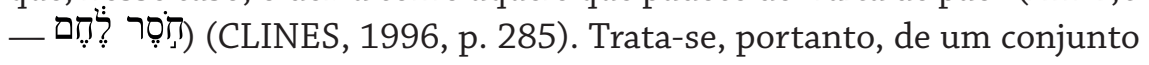
muito coeso de sentido - "escassez material do que seja imprescindível à sobrevivência”.

Nesses termos, חס aponta para a "falta de alguma coisa". Mas não precisa ser necessariamente algo de material e relacionado às condições de manutenção da vida. Na forma de substantivo, encontramos o uso da raiz na expressão idiomática "falta de coração", "lack of heart" (CLINES,

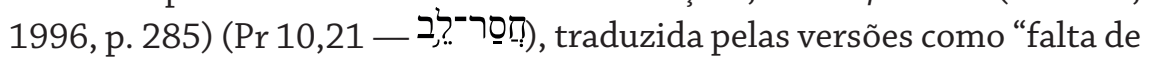
entendimento". Não incomum na BHS, essa construção idiomática ocorre em maior número com a atualização de 7 n na forma de adjetivo $(\operatorname{Pr} 6,32$; $7,7 ; 9,4.16 ; 10,13 ; 11,12 ; 12,11 ; 15,21 ; 17,18 ; 24,30)$. No conjunto, o sentido abstrato de "falta(o) de 'entendimento" interessa ao presente estudo, pelo fato de que se verifica a possibilidade de, em Salmo 23, o sentido de חס poder ser excêntrico àquele mais comum à raiz, na hipótese de, em lugar de ali se traduzir "não terei falta de nada", traduzir-se "não faltarei", como quem diz "não morrerei". Nesse caso, deve-se ter em mente que, na forma de substantivo, חס não assume apenas a forma concreta do indicativo de ausência material de condições de sobrevivência, mas presta-se à construção de pelo menos uma segunda referência de sentido, e, nesse caso, bastante abstrata.

\section{As atualizações de חס na forma de adjetivo na Bíblia Hebraica}

Alonso-Schökel reserva um verbete para חסר na forma de adjetivo, que se transcreve:

Falto, necessitado, escasso, carente, privado [...] 1 Sm 21,16 1 Re 11,22 [...]. Compostos:

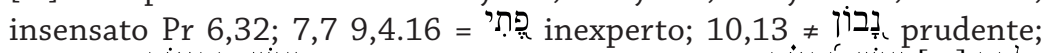

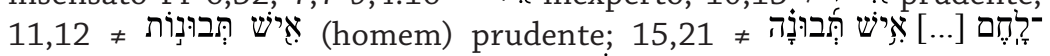

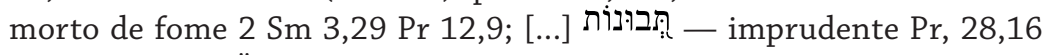
(ALONSO-SCHÖKEL, 1997, p. 237).

Vimos que a expressão "falta de 'entendimento" constrói-se majoritariamente com o recurso à atualização de חסר como adjetivo, nesse 
caso, "falto de 'entendimento"' (Pr 6,32; 7,7; 9,4.16; 10,13; 11,12; 12,11; $15,21 ; 17,18 ; 24,30)$, a cujo conjunto se deveria acrescentar o predicativo de Ec 10,3 ("o coração dele é falto" -

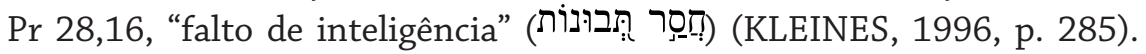
Nesse caso, trata-se da maior concentração das ocorrências de como adjetivo. Em tradução livre, o resultado da expressão ou menos algo como "falto de coração", isto é, "falto de 'entendimento"” (KLEINES, 1996, p. 285). No conjunto, aquelas ocorrências descrevem uma pessoa que, aos olhos da moral de quem redige os provérbios, comporta-se em desconformidade com os padrões considerados adequados, o que se traduz pela percepção de que isso se deve ao fato de que lhe falta correção de propósito. Alternativamente, caracteriza a condição da pessoa simplória, à qual faltam as condições de pensamento mais adequadas à vida prática, experimentada sempre nos termos da pragmática do compositor do provérbio.

Todavia, há exceções. De um lado, em 2 Sm 3,29 e Pr 12,9, o adjetivo é empregado em fórmula que expressa escassez e necessidade: "falto

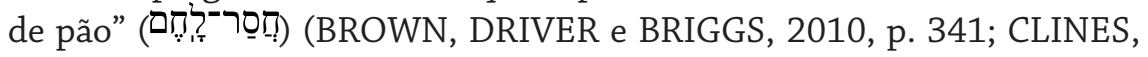
1996, p. 285). Com um sentido perceptivelmente mais ampliado, mas ainda no campo semântico da manutenção de condições de vida, deve-se incluir nesse conjunto a ocorrência de 1 Re 11,22, na qual se questiona a alguém desejoso de partir o que lhe estaria faltando tanto na situação atual que produza nele o desejo de ir embora ( tu tens falta comigo?"), fórmula que se poderia interpretar como "do que tens falta?", o que imediatamente traz à tona a referência a Ec 6,2, onde se descreve a condição de um homem provido de riquezas e que, portanto,

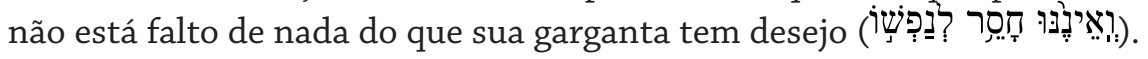
E, finalmente, o último caso de emprego do adjetivo de rom sentido figurado é $1 \mathrm{Sm}$ 21,16, onde se flagra a expressão idiomática "falto de

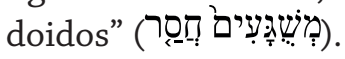

Em síntese, a raiz חסר presta-se bem à construção de frases em que se atualize como adjetivo ("falto"), indicando com isso tanto o fato de se ser falto de algo abstrato ("entendimento", "inteligência"), quanto o fato de se ser falto de algo concreto ("pão"), ainda que em uma fórmula metafórica ("falto de doidos"). Nesse âmbito semântico-fenomenológico, 
não estamos fortalecendo a hipótese de traduzir-se a ocorrência de Salmo 23,1 como "não faltarei", uma vez que todas as atualizações da raiz na forma de adjetivo são transitivas, conquanto potencialmente metafóricas.

Uma vez, todavia, que, naquela passagem investigada, a forma de sua atualização seja verbal, talvez seja no campo semântico e sintático-fenomenológico das atualizações verbais da raiz no que a intuição - "não faltarei" - encontraria algum sucesso heurístico. E é exatamente o caso.

\section{As atualizações de חסר na forma de verbo piel e hifil na Bíblia Hebraica}

Na forma de verbo, חס atualiza-se na Bíblia Hebraica em três troncos: qal, piel e hifil (BROWN, DRIVER e BRIGGS, 2010, p. 341). Em relação às atualizações verbais de חס, Alonso-Schökel dá os seguintes sentidos: a) para qal, "faltar, não haver; necessitar, carecer, sentir falta, fazer falta, ter/passar necessidade; diminuir, reduzir, minguar, esgotar-se”; b) para piel, "tornar inferior"; e c) hifil, "tirar, privar" (ALONSO-SCHÖKEL, 1997, p. 237). De imediato chama atenção a primeira acepção da raiz: "faltar". O dicionário editado por Georg Fohrer assume que, para qal, a raiz significa "diminish; be empty; lack, want; suffer want", para piel, "cause to lack, cause to want" e, para hifil, "cause to want, have want" (FOHRER, 1973, p. 88). Não se encontrará nada diferente, se a consulta for a Clines, a Kleine, a Holladay ou a Brown, Driver e Briggs. Nesse caso, o "sucesso" da intuição quanto à possibilidade de traduzir-se "não faltarei” no Salmo 23,1 não depende tanto de algum segredo perdido nos léxicos e dicionários, mas na percepção de que o sentido sempre esteve disponível, esperando ser arregimentado na forma de alguma experiência de tradução.

As duas ocorrências de piel de חסר são S1 8,6 e Ec 4,8 (HOLLADAY, 2010, p. 158). No Sl 8,6, flagra-se a clássica, mas constrangedora, tradução das versões, "pouco menor o fizeste do que os anjos"3, que altera a identi-

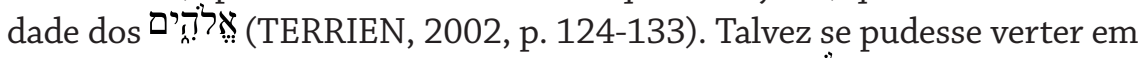

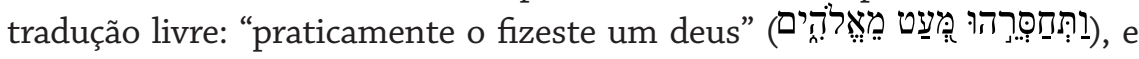
por esse procedimento de tradução, atualizar a raiz no sentido de expressar

\footnotetext{
Não se trata de "anjos", mas de "deuses" ou de "deus". A despeito de minha discordância quanto sua identificação do personagem com “cada ser humano", Cf. 0TT0, 2011, p. 138.
} 


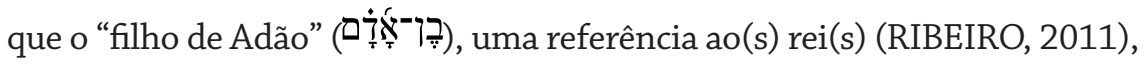
teria sido feito pouco menor do que um "deus". O sentido de "faltar (alguma coisa)" está indicado.

Por sua vez, a outra ocorrência de piel resulta mais clara: "e para que eu trabalho, privando a minha garganta do que é bom?"

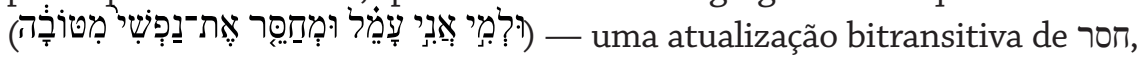
atualizando-a no sentido trivial de falto de condições de vida. Obviamente, nenhuma das duas atualizações justifica a hipótese de traduzir-se חסר no Salmo 23 como "eu faltarei". Mas lá se trata de qal...

Quanto ao hifil, as duas ocorrências são Ex 16,18 e Is 32,6 (HOLLADAY, 2010, p. 158). Em Ex 16,18, descrevendo-se a "maravilha" do maná, conta-se que "o que colhia pouco não teve falta", de sorte que o sentido de norece ser o mais comum atribuído à raiz.

Em Is 32,6, porém, ocorre uma situação diferente. Trata-se de uma situação em que, proferindo perversões contra a divindade, um "louco" termina por fazer vazia a garganta do faminto e por fazer faltar a bebida do sedento. A construção sintática pode trair a desatenção: no início do verso, e um tanto distante da oração, o sujeito de no é o "louco". Daí o emprego do hifil: o "louco" faz a água do sedento faltar. Não estamos diante do uso da raiz com o sentido de "ter falta". Ainda que, no fim das contas, ele vá ficar sem água, no que interessa à presente investigação, o que se diz sintaticamente é que a água do sedento é que vai faltar. O sujeito é "a bebida do sedento", não "o sedento", de sorte que, se no campo semântico, não faz diferença, no campo sintático, todavia, faz: o que está escrito é que "a bebida do sedento" vai faltar, não que "o sedento" vai ter falta de bebida. Desse modo, deparamo-nos com a primeira evidência: em termos sintáticos, está-se diante de um paralelo para o uso de no que se verifica ser possível identificar no Salmo 23. Aqui, o "louco" fará a água do sedento faltar (hifil). Lá, o salmista confia que não vai faltar (qal).

Em resumo, das quatro ocorrências de em piel e hifil, pelo menos uma - Is 32,6 - justifica postular-se a hipótese de traduzir-se o Salmo 23,1 como "não faltarei". 


\section{Uso de חסר como verbo qal intransitivo no sentido de faltar}

Passemos, então, às avaliações de noח em qal. Separemos as ocorrências em duas categorias: atualizações de nomo verbo transitivo e verbo intransitivo. Para não dar ao presente estudo a aparência de um romance de suspense, comecemos pelas atualizações que justificam a percepção e a hipótese de que se possa traduzir Salmo 23,1 como "não faltarei”, e que, portanto, se somarão à ocorrência de Is 32,6.

Mera coincidência, certamente, mas as duas primeiras ocorrências de חסר na Bíblia Hebraica apresentam-se como a primeira testemunha a ratificar aquela hipótese. Trata-se tanto de Gênesis 8,3 quanto 8,5. Trata-se do dilúvio. São as águas do dilúvio que mínguam, isto é, que escoam, se vão, acabam, escorrem... Literalmente, as águas "vão faltando". Depois de terem coberto a terra, devem se retirar, ocasião em que, para tanto: "foram faltando as águas" (Gn 8,3:

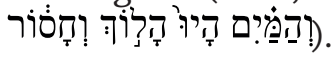

Estamos diante de uma atualização de חס que justifica totalmente a tradução "não faltarei" no Salmo 23. Se em Gênesis 8,3.5 as águas "vão faltando", isto é, escoam, no Sl 23,1 o salmista "não faltará”, isto é, não morrerá. Com isso, não se avança no sentido da exegese do Salmo 23, deve-se registrar. Apenas e tão somente se evidencia, e este é o objetivo desse estudo, que, na famosa passagem do salmo, é possível a tradução de חסר com o sentido intransitivo de "faltar", assumindo-se, então, tratar-se de um idiomatismo que, nesse caso sim, a exegese revelaria tratar-se de metáfora para a morte: "faltar" é "morrer", de sorte que "não faltar" é "não morrer". Gênesis 8,3.5 justificam plenamente a hipótese.

As duas ocorrências de Gênesis 8,3.5, todavia, não estão sozinhas. Para nos mantermos no reino das coincidências, a terceira ocorrência de חס na Bíblia Hebraica ratifica a percepção a que se chega por meio das duas primeiras atualizações analisadas. Trata-se de Gênesis 18,28.

No caso de Gn 18,28, não é que "faltem" no sentido de morrer, mas que "faltem" cinco justos de um total suficiente deles para que a divindade não destrua a cidade que ele pretende destruir justamente pela total falta

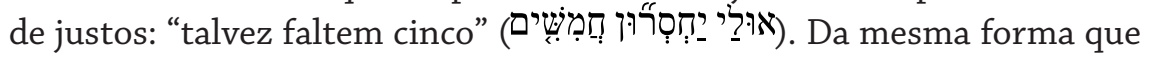
no caso de Gn 8,3.5, onde não é que "falte" alguma coisa às águas, mas é 
que as próprias águas é que se "vão faltando", indo, refluindo, retirando, no caso de Gn 18,28, não é que "falte" alguma coisa aos justos da cidade, mas, dentre um número que seria tolerável para a divindade, talvez "faltem" apenas cinco justos nela. Pela hipótese investigada, no Sl 23,1, o salmista declara confiar que não vai "faltar", isto é, morrer. Por sua vez, em Gn 18,28, "faltam" apenas cinco justos da cidade, ou seja, até deveriam estar lá, mas não estão, não existem (mais). Em todos esses casos, trata-se de "faltar" em sentido intransitivo e, no conjunto, as três ocorrências de Gênesis justificam a proposta que se faz de tradução do Salmo 23.

Há mais casos, todavia. Nas duas ocorrências de 1 Reis, 17,14.16, em razão da oferta que a senhora haverá de lhe fazer, está o "profeta" em poder de dizer que, por "maravilha" da divindade, não haverá de "faltar" farinha e azeite nos jarros de sua casa (RIBEIRO, 2004). A ideia é clara. Trata-se do azeite e da farinha: a senhora não está interessada em que nunca se acabe o jarro ou a vasilha. A questão é que não se acabem a farinha e o óleo! Todavia, a construção da frase encarrega ao uso intransitivo de חסר a tarefa de exprimir tal ideia, de sorte que o resultado é bastante curioso: "a vasilha da farinha não acabará e o jarro do óleo não faltará"

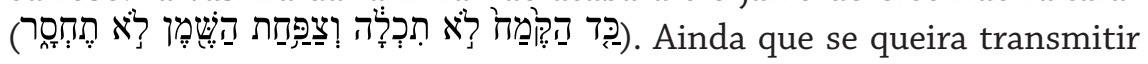
a mensagem de que a senhora, se ofertar, não terá falta de óleo e farinha, utilizando-se para expressá-la está um texto que toma por sujeito não a farinha ou o óleo, mas a vasilha da farinha e o jarro do óleo. São os jarros que não vão acabar e faltar. No texto, o uso paralelo de חלה e כלה impõe àquela o sentido mais comum desta raiz (ALONSO-SCHÖKEL, 1997, p. 316-317). Em resumo, no que diz respeito exclusivamente ao trato sintático, 1 Re 17,14.16 funciona como um paralelo para o uso de חסר Salmo 23,1: o jarro e a vasilha de farinha e de óleo não vão "faltar" nem "acabar" para a senhora de 1 Reis 17,14.16, e o personagem narrador do Salmo 23 não vai "faltar", "morrer". A hipótese é, mais uma vez, tornada plausível.

Ainda outra testemunha pode ser evocada. Eclesiastes 9,8 trata do homem que, diante do agrado de Deus, usufrui de bênçãos e de bens, em cuja cabeça de quem, então, se recomenda que não falte óleo: "e óleo sobre

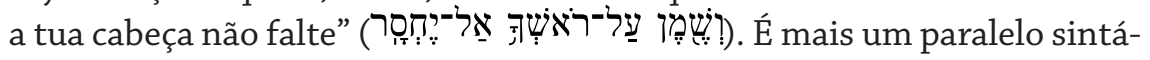
tico à construção frasal de Salmo 23,1. 
Já são sete os casos. No oitavo, elevando-se às alturas da metáfora poético-erótica, preso pelas suas tranças, assistindo-a acintosamente dançar à sua frente, um inebriado Amado observa o ventre voluptuoso da Amada e descreve poeticamente o seu umbigo como uma taça na qual não falta o "vinho": "o teu umbigo, uma tigela de redondeza - não falta o 'vi-

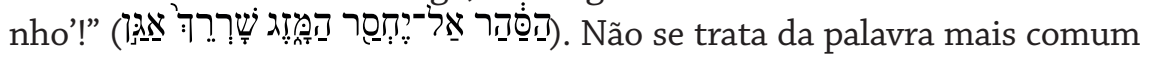
para "vinho", mas essa não é a questão: ainda que se esteja imaginando o ventre da dançarina como uma taça na qual não falta o "vinho", a estrutura sintática da narrativa é do mesmo tipo da que está presente em Ec 9,8. O sujeito, "vinho", não "falta" na taça-ventre da Amada. O sujeito não tem falta de alguma coisa - é o próprio sujeito que "falta", ou "não falta". No caso do ventre-taça, o "vinho" "não falta". No caso do Salmo 23, o salmista confia que não "vai - ele! - faltar".

Finalmente, nono caso, em contexto de profecias de libertação, Is 51,14 fala que não "faltará" o pão ao exilado: "e não faltará o pão dele"

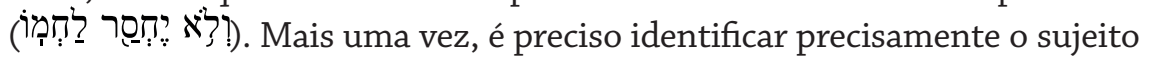
de חסר. Nesse caso, o sujeito é "o pão dele". A divindade exorta o povo à confiança, e assevera que em razão de seus cuidados, o exilado será liberto e seu pão não "vai (mais) faltar". Ora, não se pode forçar o texto a sugerir que "o pão dele" terá falta de alguma coisa. A única leitura possível é a acepção intransitiva da atualização verbal de חס: "o pão dele não faltará" - o que nos remete diretamente ao Salmo 23: também porque confia na divindade, o salmista crê que (como o pão do exilado) ele mesmo "não faltará".

\section{Uso de חסר como verbo intransitivo no sentido ambíguo: faltar ou ter falta?}

Já Neemias 9,21 é um caso interessante. Está-se diante de חס atualizada na forma de verbo intransitivo, mas não é absolutamente certo que o sentido seja "faltar". Pode ser que se trate de "ter falta". A fórmula é ("não faltaram" ou "não tiveram falta") e, com exceção da pessoa verbal, é

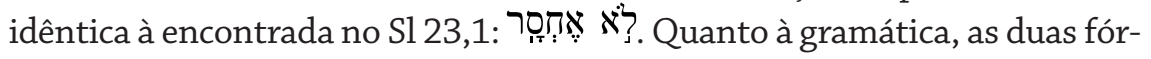
mulas podem ser traduzidas da mesma forma, seja "não faltarei / não faltaram" (Sl 23,1), seja "não terei falta / não tiveram falta" (Ne 9,21). Não será, portanto, a gramática a decidir, conquanto a gramática preste o serviço de permitir a questão da adequada tradução, uma vez que se pode traduzir, 
gramaticalmente, de uma ou de outra forma. E disso estamos cientes, dado termos nos deparado com Gn 8,3.5; 18,28; 1 Re 17,14.16; Ec 9,8; Ct 7,3 e Is 51,14 (qal) e Is 32,6 (hifil), onde foram identificadas atualizações de como "faltar", e não como "ter falta".

Penso que dificilmente haverá alguma relação intertextual e mesmo ideológica entre Salmo 23 e Neemias 9,5b-37. Todavia, não deixa de ser pelo menos curiosa a coincidência da raiz no ser empregada nas duas passagens em contexto de recurso à divindade, logo após o que aparece a cena dos inimigos sendo derrotados e humilhados. Seja qual for o sentido que se lhes vai dar, nos dois textos, trata-se de descrever o cuidado e a proteção divina em relação aos sujeitos da narrativa, no desenvolvimento dos quais aparece a figura dos inimigos vencidos e humilhados: no salmo, os inimigos à mesa do salmista (Sl 23,5), e, em Neemias, os cananeus derrotados e humilhados (Neemias 9,24-25) (COGGINS, 1976, p. 67-143).

Neemias 9,5b-37 consiste na apresentação do tema da travessia do deserto como chave de leitura da história de Judá. Recuperam-se os temas da criação $(9,6)$, dos patriarcas $(9,8)$, do êxodo $(9,9-12)$, do Sinai $(9,13-14)$ e da caminhada pós-Sinai e da Conquista $(9,15-37)$. É no contexto da caminhada pós-Sinai que aparece חס: a divindade não abandona os murmuradores no deserto, onde morreriam; antes, sua nuvem e sua coluna de fogo guiam-nos em segurança, proporcionando-lhes sombra, de dia, e luz, de noite (Neemias 9,19). A divindade deu-lhes de comer, de modo a não perecerem $(9,20)$ e, finalmente,

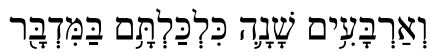

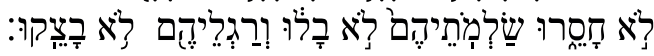

Como se deveria traduzir Neemias 9,21? "Quarenta anos sustentaste-os no deserto: não 'tiveram falta', suas vestes não se consumiram, e os seus pés não incharam", ou "quarenta anos sustentaste-os no deserto: 'não faltaram', suas vestes não se consumiram e seus pés não incharam?". Estamos diante de um caso em que deveríamos traduzir a raiz como em Gn 8,3.5; 18,28; 1 Re 17,14.16; Ec 9,8; Ct 7,3 e Is 51,14, "faltar" ou "não faltar", e, nesse caso, estaríamos diante de um paralelo perfeito em relação ao Salmo 23,1, "não faltarei", já que, nos dois casos, "faltar" serviria 
como metáfora para morrer, ou não, deve-se traduzir nom em Neemias 9,21 como "ter falta"? Não seria implausível considerar-se que Neemias 9,21 trate da condição das pessoas que, protegidas pela divindade, não "faltaram", isto é, não morreram no deserto. Não terem faltado é prova do cuidado divino, que, a julgar pelo hino a que se está recorrendo, foi tanto, que sequer os seus pés incharam, quanto mais terem faltado. Não há nada no texto que pareça indiscutivelmente interditar essa leitura. Por outro lado, também não há nada no texto que pareça indiscutivelmente defendê-la. Como se disse, em Neemias 9,21, o sentido de רon é ambíguo.

Alertados quanto a substituição do sujeito nas versões que traduzem dinamicamente o Salmo 23,1 como "nada me faltará", quando, literalmente, se poderia, sendo o caso, traduzir-se como "não terei falta", $\operatorname{Pr}$ 31,11 apresenta uma dificuldade específica. O texto hebraico fala da mu-

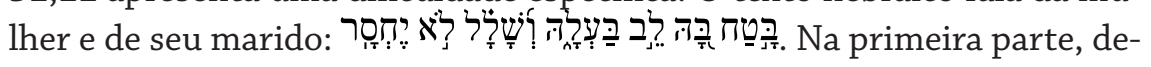
clara-se que "confiado está nela o coração do homem dela". Já na segunda, שָָׁ é uma palavra de gênero masculino e a pessoa do verbo רon é também masculina, de terceira pessoa. Se o que se quer dizer é que o marido dela não terá falta de "lucro", então se está diante do caso de qal no sentido de "ter falta”, transitivo, e se deve traduzir "confiado nela está o coração dele, e ele não terá falta de lucro", isto é, ele, o marido dela. É o que me parece mais natural. Todavia, se se opta por considerar que, por força das atividades dela, no que está confiado o coração do marido, o lucro não vai faltar, então se está diante de mais um caso intransitivo, e, nesse sentido, mais um possível apoio gramatical para a experiência de traduzir Salmo 23,1 como "não faltarei". Dada a ambiguidade da passagem, todavia, convém incluí-la como um dos dois casos de ambiguidade da raiz, e contentarmonos com os nove casos já encontrados que sustentam sem dificuldades do sentido de חסר como "faltar" e, nesses casos, não como "ter falta".

\section{Uso de como verbo intransitivo no sentido de "ter falta"}

Convém advertir que mesmo o uso intransitivo de חסר pode sustentar o sentido de privação de bens, de modo que a tradução conveniente não seja "faltar", mas "ter falta". É o caso de $\operatorname{Pr} 13,25$, que, a despeito da condição intransitiva da raiz, pelo contexto poético em paralelismo da 
passagem, transparece perfeitamente bem o sentido de "ter falta" como contrário de "ter saciedade":

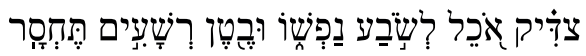

"O justo come à satisfação de sua garganta, mas o ventre do injusto terá falta"

Uma vez que os dois estíquios do verso encontram-se elaborados

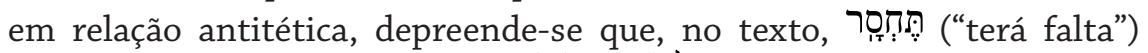

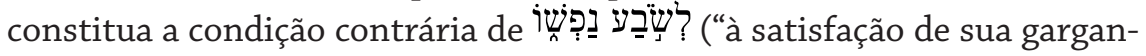
ta"). Está, portanto, implícita a ideia de que o injusto terá falta daquilo que o justo terá em abundância.

\section{Uso de רסח como verbo transitivo no sentido de "ter falta"}

Ao contrário do uso intransitivo de חסר, que pode atualizar a raiz com qualquer dos seus dois sentidos gerais, "ter falta" ou "faltar", o uso transitivo do verbo é sempre flagrado no sentido de "ter falta". Talvez seja essa a razão de Salmo 23,1 receber esse tratamento. Vamos aos casos.

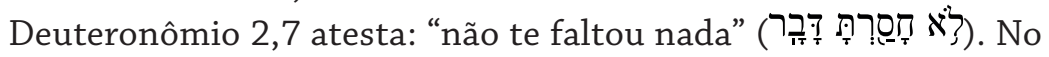
contexto, fala-se que, durante os quarenta anos de caminhada do povo no deserto, não lhe faltou nada. Estamos diante da mesma tradição presente no hino de Neemias 9,21. Todavia, em Dt 2,7 pareceu ao escritor necessário contornar a ambiguidade do verbo, incluindo o objeto direto

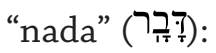

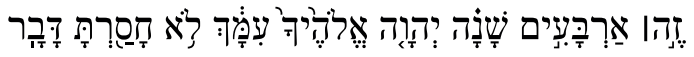

"Estes quarenta anos que Yahweh esteve contigo, não te faltou nada"

Por sua vez, em Deuteronômio 8,9, fala-se que a terra que os "judeus" do êxodo receberiam da divindade era de tal modo abençoada que, lá, não teriam falta de nada: "não terás falta de nada nela"

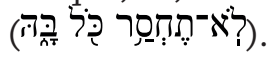


Em Deuteronômio 15,8, fala-se de emprestar ao pobre da terra aquilo que lhe falta para suas necessidades básicas: "o que falta para ele"

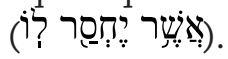

Em Salmo 34,11, declara-se que aqueles que buscam a Yahweh não têm falta de tudo quanto é bom: "não têm falta de tudo que é bom"

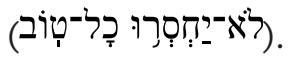

Jr 44,18 põe a confessar os adoradores da Rainha dos Céus que, cessado o culto à deusa, passaram a ter falta de tudo: "tivemos falta de

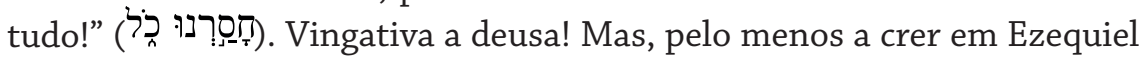
4,17, também dessa vez por encargo divino, é a mesma falta que se diz estar sendo preparada, agora por Yahweh, que tomará medidas "para que

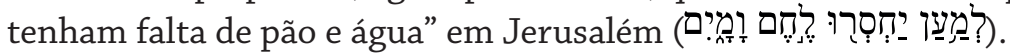

\section{Considerações finais}

O presente artigo partiu de uma intuição: e se a tradução de

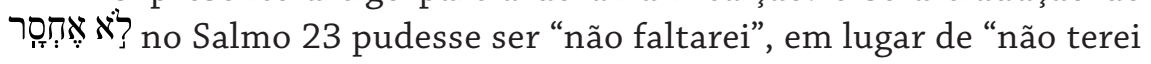
falta" (que as versões transformam em "nada me faltará”)? Trata-se de um primeiro estudo, cuja série tem por pretensão a tradução e a interpretação do salmo. Para o primeiro estudo, era necessário verificar se suportava tanto semântica quanto sintaticamente a tradução. Era, pois, necessário verificar todas as ocorrências da raiz na Bíblia Hebraica, considerando-se ser esta o escopo fenomenológico mais adequado para a sondagem.

Após o exercício, constata-se que a raiz se atualiza na BHS com forma de substantivo, adjetivo e verbo. Na forma de verbo, atualiza-se na forma de qal, piel e hifil. Na forma verbal de qal, e no seu uso intransitivo, foram constatadas passagens que inequivocamente sustentam a tradução pretendida para Salmo 23,1. Devem ser traduzidas com o sentido de "faltar" Gênesis 8,3.5; 18,28; 1 Re 17,14.16; Ec 9.8; Ct 7,3 e Is 51,14 . A essas, some-se a ocorrência de hifil em Is 32,6. No conjunto, são nove ocorrências. Além dessas nove, mas agora marcadas por perceptível ambiguidade, devem-se mencionar as ocorrências de $\mathrm{Ne}$ 9,21 e $\operatorname{Pr} 31,11$. Em resumo, são nove paralelos sintático-semânticos possíveis e dois potencialmente possíveis como instrumento retórico 
de defesa da hipótese de tradução de Salmo 23,1 como "o Senhor é meu pastor, não faltarei".

Como recurso de prova retórica, convém sintetizar o resumo em um novo quadro esquemático:

Quadro 2 - Paralelos sintáticos da Bíblia Hebraica do uso de חסר no Salmo 23

\begin{tabular}{|c|c|c|c|}
\hline & Sujeito & Verbo (רס) & Predicado \\
\hline \multirow{2}{*}{ Gn 8,3} & הַטְַּים & 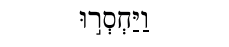 & \\
\hline & As águas & foram faltando & \\
\hline \multirow{2}{*}{ Gn 8,5} & 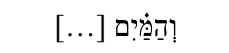 & וחדָסוֹר & \\
\hline & E as águas & [...] foram faltando & \\
\hline \multirow{2}{*}{ Gn 18,28} & 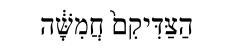 & - יְחְסִרוּן & \\
\hline & (Se) os cinco justos & faltarem & \\
\hline \multirow{2}{*}{ Is 32,6} & 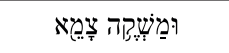 & יוּחְסִיר & \\
\hline & A água do sedento & ele faz faltar ${ }^{4}$ & \\
\hline \multirow{2}{*}{$1 \operatorname{Re} 17,14$} & 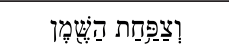 & לְא תֶחְסָר & \\
\hline & E o jarro do óleo & não faltará & \\
\hline \multirow{2}{*}{$1 \operatorname{Re} 17,16$} & 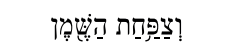 & לִא חָסֵר & \\
\hline & E o jarro do óleo & não faltou & \\
\hline \multirow{2}{*}{ Ct 7,3} & 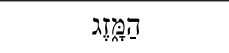 & אַל-יְיחתסֵר & \\
\hline & O “vinho" & não falta & \\
\hline \multirow{2}{*}{ Is 51.14} & לַחְמְוֹוֹ & 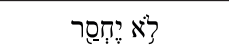 & \\
\hline & 0 pão dele & não falta & \\
\hline \multirow{2}{*}{ Ec 9,8} & 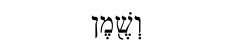 & אַל־־יְחָסָר & עַל־ראשֶֶּׁ \\
\hline & E óleo & não falte & sobre a tua cabeça \\
\hline \multirow{2}{*}{ SI 23,1 } & & לִא אֶחְסרך & \\
\hline & & Não faltarei & \\
\hline
\end{tabular}

Fonte: elaborado pelo autor. 
Os nove casos constituem-se paralelos perfeitos ao uso de חסר no Salmo 23. Em todos os nove casos, dos sujeitos se diz que "faltam" (Gn $8,3.5 ; 18,28$. Is 32,6) ou que "não faltam" (1 Re 17,14.16; Ec 9,8; Ct 7,3; Is $51,14)$ e não que "têm falta de alguma coisa" ou que "não têm falta de alguma coisa", sentido que se expressa apenas nas demais ocorrências da raiz na BHS. Das nove ocorrências, cinco flagram-se inclusive com a forma negativa, presente no Salmo 23,1 - nesse caso, "não faltar". Considero justificada a hipótese de que se pode traduzir a fórmula לָא 23,1 como "não faltarei". E, a rigor, não se trata mais de simples hipótese, mas de tese, que, salvo melhor juízo, penso plenamente defendida.

Descobrir-se, todavia, que a tradução é gramaticalmente possível, de modo que a tese se sustenta, não é a mesma coisa que demonstrar que mais do que possível, ela é imperiosa. O fato de o Salmo 23,1 poder ser traduzido assim não significa que ele tenha que ser traduzido assim. Mais do que funcionar no léxico semântico-fenomenológico da BHS, a tradução "não faltarei" deverá funcionar ainda mais adequadamente do que "não terei falta", no tecido inteiro do Salmo 23. Para tanto, requer-se um segundo estudo, que deverá investigar, no Salmo 23, a relação entre o tratamento da divindade como "pastor" e a referência à mesa e aos inimigos, no v. 5, duas ideias que deverão apontar, é a nova hipótese, para a identidade do autor implícito como rei. Rei que, ameaçada a sua vida pelos inimigos do v. 5 , confia que a divindade há de protegê-lo, que vai vencer seus inimigos e que, vitorioso, presidirá à mesa da vitória diante deles...

\section{Referências}

ALONSO-SCHÖKEL, L. Dicionário bíblico hebraico-português. São Paulo, Paulus, 1997.

BROWN, F.; DRIVER, S. R.; BRIGGS, A. The Brown-Driver-Briggs Hebrew and English lexicon. S.L.: Snowpublishing, 2010.

4 Apenas para esclarecimento: "ele faz faltar a água do sedento" resulta em um período composto, no qual "a água do sedente faltar" funciona como oração subordinada substantiva objetiva direta, da qual a oração principal funciona como sujeito: o que "ele faz"? "Ele faz a água do sedento faltar". Todavia, naquela que constitui subordinada em relação à oração principal, “a água do sedento” é sujeito do verbo "faltar". 0 efeito sintático deriva do verbo hebraico no causativo (hifil).

Rev. Pistis Prax., Teol. Pastor., Curitiba, v. 9, n. 2, 721-739, set./dez. 2017 
CLINES, D. J. A. (ed). The dictionary of classical Hebrew. v. III. Sheffield: Sheffield Academic Press, 1996.

COGGINS, R. J. The Books of Ezra and Nehemiah. London: Cambridge, 1976.

FOHRER, G. (org). Hebrew and Aramaic dictionary of the Old Testament. Berlin: Walter de Gruyter, 1973.

GINZBURG, C. Relações de força: História, retórica, prova. São Paulo: Companhia das Letras, 2002.

HOLLADAY, W. L. Léxico hebraico e aramaico do Antigo Testamento. São Paulo: Vida Nova, 2010.

KLEIN, E. A comprehensive ethymological dictionary of the Hebrew language for readers of English. Jerusalém: Carta, 1987.

OTTO, E. The Judean legitimation of royal rulers in its ancient near eastern contexts. In: HUMAN, D. J.; VOS, C. J. A. (org). Psalms in liturgy. London: T\&T Clark, 2004, p. 131-139.

RIBEIRO, O. L. "A lembrança de minhas faltas...". Reflexões sobre a estrutura mítico-literária de 1 Re 17. Revista Brasileira de Teologia, Rio de Janeiro, n. 2, p. 17-35, 2004.

RIBEIRO, O. L. Os “fillhos de Adão" na Bíblia Hebraica. Reflexus, v. 5, n. 6, 2011, p. 145-161.

TERRIEN, S. L. The Psalms: strophic and theological commentary. Grand Rapids: William B. Eerdman Publishing Company, 2002.

WOODS, E. J. Deuteronomy: An introduction and commentary. Grove: InterVarsity Press, 2011.

Recebido: 22/11/2016

Received: 11/22/2016

Aprovado: 25/05/2017

Approved: 05/25/2017 